T) JURNAL BASICEDU

Volume 6 Nomor 1 Tahun 2022 Halaman 1435 - 1439

Research \& Learning in Elementary Education

https://jbasic.org/index.php/basicedu

$P$ AHLAWAN

\title{
Pengembangan Bahan Ajar E-Learning untuk Meningkatkan Kualitas Pembelajaran Mata Kuliah Biologi Umum STKIP Muhammadiyah Manokwari selama Masa Pandemi Covid 19 dan Era New Normal
}

\author{
Revisika $^{1 凶}$, Wiska Baharuddin ${ }^{2}$, Enik Maturahmah $^{3}$ \\ Pendidikan Biologi, STKIP Muhammadiyah Manokwari, Indonesia ${ }^{1,2,3}$ \\ E-mail: 85revisika@gmail.com¹‥wiskab7@gmail.com² ${ }^{2}$ maturahmahenik@gmail.com ${ }^{3}$
}

\begin{abstract}
Abstrak
Moodle merupakan salah satu LMS yang digunakan dalam PBJJ di STKIP Muhammadiyah. Selain itu perlu untuk mempertahankan kualitas pendidikan selama Pandemi Covid 19 dengan peningkatan kualitas pembelajaran yang dilakukan secara daring. Oleh karena itu, perlu adanya pengembangan bahan ajar e-learning untuk meningkatkan kualitas pembelajaran Mata Kuliah Biologi Umum di STKIP Muhammadiyah Manokwari Selama Masa Pandemi Covid 19 dan Era New Normal. Metode penelitian pengembangan ini yaitu research and development (R\&D) dengan desain 4D, yaitu tahap define, design, develop, dan disseminate. yang dibatasi sampai tahap develop. Tahap pengembangan dilakukan validasi bahan ajar kemudian uji kelompok kecil dan kelompok besar. Indikator yang diuji berupa tampilan, kepraktisan, pedagogik, materi. Persentase kepraktisan memiliki nilai paling tinggi diantara keempat indikator tersebut. Kepraktisan sebesar 86,8\% untuk uji kelompok kecil dan 87,2 \% untuk uji coba kelompok besar. Penelitian ini diharapkan untuk meningkatkan kualitas pembelajaran Mata Kuliah Biologi Umum. Peningkatan kualitas pembelajaran ditinjau berdasarkan keberhasilan penggunaan e-learning dengan peningkatan prestasi akademik mahasiswa. Dampak penggunaan e-learning juga untuk melihat kesiapan mahasiswa Pendidikan Biologi yang merupakan calon guru terhadap penggunaan teknologi.
\end{abstract}

Kata Kunci: e-learning, Moodle, Belajar Daring, Covid 19, kualitas pembelajaran.

\begin{abstract}
Moodle is one of the LMS used in PBJJ at STKIP Muhammadiyah. This is to comply with government programs and students still have the right to acquire knowledge but remain safe by staying at home. In addition, it is necessary to maintain the quality of education during the Covid-19 pandemic by improving the quality of learning that is carried out without face to face. Therefore, it is necessary to develop e-learning teaching materials to improve the quality of learning for General Biology Courses at STKIP Muhammadiyah Manokwari during the Covid 19 Pandemic and the New Normal Era. In the development stage, validation of teaching materials was carried out, then small group and large group tests were carried out. The indicators tested are appearance, practicality, pedagogic, material. The percentage of practicality has the highest value among the four indicators. Practicality is $86.8 \%$ for small group trials and $87.2 \%$ for large group trials. This research is expected to improve the quality of learning in General Biology. Improving the quality of learning is reviewed based on the successful use of e-learning with an increase in student academic achievement. The impact of using e-learning is also to see the readiness of Biology Education students who are prospective teachers to use technology.
\end{abstract}

Keywords: e-learning, Moodle, Online Learning, Covid 19, learning quality.

Copyright (c) 2022 Revisika, Wiska Baharuddin, Enik Maturahmah

Corresponding author :

Email:요 revisika@gmail.com

DOI $\quad:$ https://doi.org/10.31004/basicedu.v6i1.1820

ISSN 2580-3735 (Media Cetak)

ISSN 2580-1147 (Media Online)

Jurnal Basicedu Vol 6 No 1 Tahun 2022

p-ISSN 2580-3735 e-ISSN 2580-1147 
1436 Pengembangan Bahan Ajar E-Learning untuk Meningkatkan Kualitas Pembelajaran Mata Kuliah Biologi Umum STKIP Muhammadiyah Manokwari selama Masa Pandemi Covid 19 dan Era New Normal - Revisika, Wiska Baharuddin, Enik Maturahmah

DOI : https://doi.org/10.31004/basicedu.v6i1.1820

\section{PENDAHULUAN}

Program Belajar Jarak Jauh (PBJJ) merupakan alternatif yang digunakan saat ini oleh setiap universitas untuk melaksanakan proses belajar mengajar walaupun tidak dengan tatap muka. Pendidikan jarak jauh yang diselenggarakan dengan penjaminan kualitas yang baik dan sesuai dengan kebutuhan pemangku kepentingan merupakan salah satu mekanisme perluasan akses pendidikan tinggi (Wahyudin, 2020). Universitas di tengah pandemi COVID-19 harus tetap menjalankan proses belajar mengajar dengan mengubahnya menjadi PBJJ. PBJJ ini menjadi tantangan bagi setiap universitas untuk tetap menjalankan tujuan pendidikan. Salah satunya terobosan membuat bahan ajar elektronik. Bahan Ajar elektronik berdasarkan Rencana Pembelajaran Semester (RPS) yang telah disusun. RPS tersebut memuat seluruh materi dan komponen mata kuliah Biologi Umum terdiri dari kompetensi, tujuan, indikator, hingga materi perkuliahan. Bahan ajar e-learning dalam menyajikan media dinamis merupakan kelebihan yang tidak dimiliki oleh media cetak. Bahan ajar e-learning dipillih karena memiliki kelebihan dibanding bahan ajar jenis lainnya (Diana, 2020).

E-learning adalah sistem pembelajaran yang memanfaatkan media elektronik sebagai alat untuk membantu kegiatan pembelajaran (Suryadi, 2015). Pengertian e-learning atau pembelajaran elektronik sebagai salah satu alternatif kegiatan pembelajaran dilaksanakan melalui pemanfaatan teknologi komputer dan internet. seseorang yang tidak dapat mengikuti pendidikan konvensional karena berbagai faktor penyebab, misalnya harus bekerja (time constraint), kondisi fisik yang tidak memungkinkan (physical constraint), daya tampung sekolah konvensional yang tidak memungkinkan (limited availeble seats), phobia terhadap sekolah, putus sekolah, atau karena memang di didik melalui pendidikan keluarga di rumah (home school) dimungkinkan untuk tetap belajar, yaitu melalui e-learning (Suryadi, 2015). E-learning menggunakan aplikasi elektronik untuk mendukung pengembangan kegiatan belajar mengajar dengan media internet, intranet atau media komputer yang lain.

Kelebihan pertama, bahan ajar e-learning dapat memadukan antara teks dengan media bergerak seperti animasi dan video. Perpaduan tersebut sangat bermanfaat karena bahan ajar ditampilkan secara utuh dengan kombinasi media yang lebih lengkap daripada bahan ajar cetak. Selain itu, lebih mudah memahami karena media bergerak mampu menggambarkan seperti lingkungan sebenarnya. Kelebihan kedua, bahan ajar $e$ learning dapat dimanfaatkan secara flesksibel. Flesibilitas bahan ajar e-learning yang ditampilkan di dalam web dapat dimanfaatkan tanpa terikat tempat dan waktu. Kelebihan ketiga, pemanfaatan bahan ajar e-learning untuk pembelajaran dapat meningkatkan kualitas belajar mahasiswa (Utomo, Sumarmi, \& Susilo, 2015). Kelebihan keempat, bahan ajar e-learning dapat bekerja secara otomatis karena dapat diintegrasikan dengan Learning Management System (LMS). Hal ini karena LMS begitu mudah, fleksibel, dan nyaman. Moodle merupakan salah satu LMS yang digunakan dalam PBJJ di STKIP Muhammadiyah.

Penggunaan e-learning diterapkan dalam perkuliahan daring secara keseluruhan tanpa tatap muka atau dalam jaringan (daring) selama Pandemi Covid 19 dan Era New Normal di Jurusan Pendidikan Biologi STKIP Muhammadiyah Manokwari. Hal ini dalam rangka menaati program pemerintah dan mahasiswa tetap mendapatkan haknya memperoleh ilmu tetapi tetap aman dengan di rumah saja (Khasanah , Pramudibyanto , \& Widuroyekti, 2020). Selain itu perlu untuk mempertahankan kualitas pendidikan selama ada Pandemi Covid 19 dengan peningkatan kualitas pembelajaran yang dilakukan daring. Oleh karena itu, perlu adanya pengembangan bahan ajar e-learning untuk meningkatkan kualitas pembelajaran Mata Kuliah Biologi Umum di STKIP Muhammadiyah Manokwari Selama Masa Pandemi Covid 19 dan Era New Normal.

Pembelajaran daring dilaksanakan untuk meningkatkan kualitas pembelajaran Mata Kuliah Biologi Umum. Peningkatan kualitas pembelajaran ditinjau berdasarkan keberhasilan penggunaan e-learning dengan peningkatan prestasi akademik mahasiswa. Dampak penggunaan e-learning juga untuk melihat kesiapan mahasiswa Pendidikan Biologi yang merupakan calon guru terhadap penggunaan teknologi. 
1437 Pengembangan Bahan Ajar E-Learning untuk Meningkatkan Kualitas Pembelajaran Mata Kuliah Biologi Umum STKIP Muhammadiyah Manokwari selama Masa Pandemi Covid 19 dan Era New Normal - Revisika, Wiska Baharuddin, Enik Maturahmah

DOI : https://doi.org/10.31004/basicedu.v6i1.1820

\section{METODE}

Penelitian dalam pengembangan bahan ajar e-learning ini menggunakan model Borg \& Gall. Model ini memiliki 10 langkah yang dimodifikasi dan dikelompokkan menjadi 3 tahap, yaitu: tahap (1) studi pendahuluan (research and information collecting), tahap (2) pengembangan (planning and development of the preliminary form of product), dan tahap (3) uji coba (preliminary field testing, main product revision, main field testing) (Utomo, Sumarmi, \& Susilo, 2015). Penentuan modifikasi didasarkan atas pertimbangan bahwa tujuan penelitian ini untuk satu topik bahasan, yaitu Mata Kuliah Biologi Umum. Pengembangan produk ini ada beberapa tahap yang tidak perlu dilakukan seperti: uji coba kelayakan dan diseminasi. Uji coba kelayakan tidak perlu dilakukan karena uji coba kelompok kecil dan kelompok besar sudah dapat mewakili tanggapan subjek penelitian. Adapun tahap diseminasi tidak perlu dilakukan karena penelitian difokuskan pada pengembangan produk, sedangkan diseminasi dapat dilakukan oleh peneliti lain.

Penelitian dan pengembangan ini terbatas sampai menghasilkan produk berupa bahan ajar e-learning. Bahan ajar yang dikembangkan difokuskan pada Mata Kuliah Biologi Umum. Model penelitian Borg \& Gall Tahap studi pendahuluan terdiri dari studi pustaka dan lapangan. Studi pustaka meliputi hal-hal berikut: (1) analisis kelemahan penyajian materi, (2) analisis kebutuhan penyajian materi, dan (3) studi literatur tentang hasil-hasil penelitian dan pengembangan bahan ajar e-learning. Adapun studi lapangan meliputi hal-hal berikut: (1) observasi, (2) analisis kesiapan SDM, (3) analisis sarana penunjang uji coba misalnya komputer dan jaringan internet.

Pengembangan bahan ajar e-learning menggunakan Moodle dengan tahap selanjutnya dari penelitian ini adalah pengembangan yang meliputi tiga langkah, yaitu: (1) penyusunan bahan ajar, (2) validasi ahli, dan (3) Desain e-learning. Penyusunan bahan ajar dilakukan secara daring, kemudian bahan ajar divalidasi oleh ahli materi, bahasa, dan desain pembelajaran. Hasil validasi digunakan untuk memperbaiki bahan ajar jika ada yang tidak sesuai.

Tahap akhir dari penelitian ini adalah uji coba yang terdiri dari dua uji coba yaitu uji coba kelompok kecil dan besar. Uji coba kelompok kecil terdiri dari 15 mahasiswa, sedangkan uji coba kelompok besar terdiri dari 36 mahasiswa. Penentuan subjek uji coba dipilih berdasarkan kemampuan IT dan kognitif yang rendah. Alasannya, jika bahan ajar ini mampu diterima oleh mahasiswa dengan kemampuan IT dan kognitif yang rendah, maka mahasiswa yang kemampuan IT dan kognitifnya lebih tinggi semakin mudah memahami. Setelah itu, menganalisis dampak adanya e-learning dengan meninjau prestasi akademik mahasiswa. Setelah uji produk dilakukan dibuat laporan sementara.

\section{HASIL DAN PEMBAHASAN}

Penelitian ini menghasilkan bahan ajar $e$ - learning pada Mata Kuliah Biologi umum. Penelitian ini bertujuan untuk meningkatkan kualitas Pembelajaran Mata Kuliah Biologi Umum di STKIP Muhammadiyah Manokwari. Subyek penelitian, yaitu mahasiswa/i yang mengambil Mata Kuliah Biologi Umum di STKIP Muhammadiyah manokwari pada semester ganjil 2020/201. Pembuatan e-learning menggunakan Moodle, yang dibuat oleh ahli media. Peneliti memberikan komponen dari bahan ajar dan desain bahan ajar yang dinginkan.

Pembuatan e-learning dilakukan oleh ahli media. Peneliti memberikan masukan, sehingga dilakukan beberapa revisi sebelum melakukan uji terbatas. Adanya revisi bertujuan untuk memeperoleh bahan ajar yang mendukung penelitian. Isi bahan ajar yang diterapkan di validasi oleh validator yang berkompeten dibidang Biologi dengan hasil pada Tabel 1. Aspek yang dinilai oleh validator terdiri dari keterbaccan modul, kejelasan tulisan kedalaman materi, bentuk penyajian dan kelengkapan bahan ajar. Hasil diperoleh dalam bentuk skor dengan baik hingga sangat baik, sehingga bahan ajar sudah sesuai dan siap untuk diuji cobakan. 
1438 Pengembangan Bahan Ajar E-Learning untuk Meningkatkan Kualitas Pembelajaran Mata Kuliah Biologi Umum STKIP Muhammadiyah Manokwari selama Masa Pandemi Covid 19 dan Era New Normal - Revisika, Wiska Baharuddin, Enik Maturahmah

DOI : https://doi.org/10.31004/basicedu.v6i1.1820

Tabel 1. Hasil Validasi Bahan Ajar

\begin{tabular}{lll}
\hline \multicolumn{1}{c}{ Aspek yang dinilai } & \multicolumn{1}{c}{ Skor } & \multicolumn{1}{c}{ Kriteria } \\
\hline Keterbacaan Modul & 3 & $\begin{array}{l}\text { Jelas dan dapat dipergunakan dengan revisi } \\
\text { revisi }\end{array}$ \\
\hline Kejelasan tulisan & 4 & Sangat jelas dan dapat dipergunakan tanpa revisi \\
\hline Kedalaman materi & 4 & Sangat jelas dan dapat dipergunakan tanpa revisi \\
\hline Bentuk Penyajian & 3 & Bagus \\
\hline Kelengkapan Bahan Ajar & 3 & Baik dan sesuai sehingga dapat dipergunakan \\
\hline
\end{tabular}

Nilai Skor :

$4=$ Sangat baik

$3=$ Baik

$2=$ Cukup

$1=$ Kurang

Uji coba produk dilaksanakan di Sekolah Tinggi Keguruan dan Ilmu Pendidikan (STKIP) Muhammadiyah Manokwari yaitu mahasiswa/i yang mengambil Mata Kuliah Biologi Semester Ganjil 2020/2021 (Gambar 3). Uji Coba dilakukan pada kelompok kecil dan besar. Uji coba kelompok kecil terdiri dari 15 mahasiswa, sedangkan uji coba kelompok besar melibatkan 36 mahasiswa. Uji coba produk ini untuk mengetahui kelayakakan produk melalui respon yang diberikan oleh mahasiswa (Tabel 2).

Tabel 2. Hasil Uji Coba Kelompok Kecil dan Kelompok Besar

\begin{tabular}{llccccl}
\hline \multirow{2}{*}{ No } & \multirow{2}{*}{ Indikator } & \multirow{2}{*}{ Jumlah Soal } & \multicolumn{2}{c}{ Kelompok Kecil } & \multicolumn{2}{c}{ Kelompok Besar } \\
\cline { 3 - 7 } & & $\%$ & Kategori & $\%$ & Kategori \\
\hline 1 & Tampilan & 15 & 75,1 & Baik & 78,3 & Baik \\
\hline 2 & Kepraktisan & 7 & 86,8 & Sangat Baik & 87,2 & Sangat Baik \\
\hline 3 & Pedagogik & 12 & 75,5 & Baik & 78,2 & Baik \\
\hline 4 & Materi & 11 & 81,0 & Sangat Baik & 83 & Sangat Baik \\
\hline
\end{tabular}

Pengembangan bahan ajar $e$ - learning ini bisa diakses menggunakan smartphone dan komputer. Elearning dapat digunakan sebagai alternatif pemecahan masalah dalam keterbatasan bahan ajar yang ada serta menyediakan sumber belajar yang bervariasi dan menarik bagi mahasiswa. Adanya bahan ajar elektronik yang diuji terlihat bahwa semua indikator berjalan baik untuk tampilan dan pedagogik, sedangkan kepraktisan dan materi mendapat kategori sangat baik. Evaluasi terhadap peningkatan kualitas pembelajaran biologi hanya terlihat pada nilai akhir semester, tidak ada pembanding nilai tanpa penggunaan $e$-learning. Namun adanya bahan ajar $e$ - learning membantu pada saat pandemi covid dan era New Normal terutama dalam hal kepraktisan ( Tabel 2 ).

\section{KESIMPULAN}

Penelitian ini mengahasilkan bahan ajar dengan $e$-learning. E - Learning diujikan pada uji kelompok kecil pada 15 mahasiswa dan uji kelompok besar pada 36 mahasiswa. Bahan ajar elektronik ini hanya dapat dijalankan diperangkat smartphone atau komputer. Adanya bahan ajar elektronik yang diuji terlihat bahwa semua indikator berjalan baik untuk tampilan dan pedagogik, sedangkan kepraktisan dan materi mendapat kategori sangat baik. 
1439 Pengembangan Bahan Ajar E-Learning untuk Meningkatkan Kualitas Pembelajaran Mata Kuliah Biologi Umum STKIP Muhammadiyah Manokwari selama Masa Pandemi Covid 19 dan Era New Normal - Revisika, Wiska Baharuddin, Enik Maturahmah

DOI : https://doi.org/10.31004/basicedu.v6i1.1820

Pengembangan bahan ajar elektronik ini memiliki beberapa kelebihan sebagai alternatif pemecahan masalah dalam keterbatasan bahan ajar yang ada Bahan ajar elektronik masuk kategori cukup baik dan efektif digunakan sebagai bahan ajar. Bahan ajar elektronik dapat menambah pemahaman mahasiswa mengenai materi yang dijelaskan dosen didalam kelas.

\section{UCAPAN TERIMA KASIH}

Terimakasih kami ucapkan kepada Tuhan Yang Maha Esa atas berkatnya sehingga kami bisa menyelesaikan penelitian ini, Ketua STKIP Muhammadiyah Manokwari dan jajarannya, bapak/ibu dosen dan pegawai di lingkungan STKIP Muhammadiyah yang telah mendukung kami mengadakan riset dengan judul Pengembangan Bahan Ajar E- Learning Untuk meningkatkan Kualitas Pembelajaran Mata Kuliah Biologi Umum di STKIP Muhammadiyah Manokwari. Kami juga mengucapkan terimakasih kepada mahasiswa/i STKIP Muhammadiyah Manokwari yang telah bersedia menjadi responden kami, semoga kita tetap sehat selalu dan semangat dalam belajar.

\section{DAFTAR PUSTAKA}

Arsyad, A. (2014). Media Pembelajaran. Jakarta: Rajawali Pers.

Diana, N. A. (2020, Juni). Plus Minus Penggunaan Aplikasi-Aplikasi Pembelajaran Daring Selama Pandemi Covid-19. Unimed Medan, 1-11.

Khasanah , D., Pramudibyanto , H., \& Widuroyekti. (2020, Agustus 06). Pendidikan Dalam Masa Pandemi Covid-19. $\quad$ Sinestesia, 10(1), 41-8. $\quad$ Retrieved $\quad$ From Https://Sinestesia.Pustaka.My.Id/Journal/Article/View/44

Nurmaya, A. L., Irsan, \& Lestari, A. A. (2021). Analisis Evaluasi Pembelajaran Daring (Online) Sekolah Dasar Selama Pandemi Covid 19. Jurnal Kajian Pendidkan Dasar (Jkpd), 6(1).

Prastowo, A. (2011). Panduan Kreatif Membuat Bahan Ajar Inovatif, Menciptakan. Jogjakarta: Diva Press. Jogjakarta: Diva Press.

Ribawati,Eka. (2019). Pengembangan Bahan Ajar E-Learning Pada Mata Kuliah Sejarah Afrika. Candrasangkala: Jurnal Pendidikan Dan Sejarah, 5(1), 23-29.

Riyanda, A. R. (2020). Evaluasi Implementasi Sistem Pembelajaran Daring Fakultas Keguruan Dan Ilmu Pendidikan Universitas Lampung. Ikra-Ith Humaniora. 4(1), 66-71.

Rusdiana, E., \& Nugroho, A. (2020). Respon Mahasiswa Pada Pembelajaran Daring Bagi Mahasiswa Mata Kuliah Pengantar Hukum Indonesia Unesa. Integralistik, 31(1), 1-12.

Sari , D. (2020). Peran Adaptif Tiga Universitas Di Jabodetabek Dalam Menghadapi Sistem Belajar Online Selama Pandemi Covid 19. Prosiding Seminar Nasional Hardiknas 1, (Pp. 25 -32).

Suryadi, S. (2015). Prospek Sistem E-Learning Dalam Pemanfaatan Teknologi Transformasi Telekomunikasi Untuk Kegiatan Pembelajaran Di Perguruan Tinggi Di Indonesia. Informatika Amik Lb Medan, 3.

Utomo, D. S., Sumarmi, \& Susilo, S. (2015). Pengembangan Bahan Ajar E-Learning Berbasis Edmodo Pada Materi Litosfer Kelas X Sma. Jurnal Pendidikan Geografi, 20(2).

Wahyudin, D. (2020). Pengelolaan Pembelajaran Jarak Jauh : Kajian Dasar Hukum Dan Respon Mahasiswa. Digit Libr Uin Sunan Gunung Jati [Internet], 1-11.

Wicaksana , E. J., \& Atmadja , P. (2018). Analisis Dampak Program Guru Pendamping Direktorat Psmk (Program Sm3t) Terhadap Animo Belajar Peserta Didik Pada Mata Pelajaran Biologi Di Smkn 1 Kintamani, Bali. Biodik, Vol.4(No.2), 110-119. 